\title{
Perancangan Prototipe Receiver Beacon Black Box Locator Acoustic 37,5 kHz Pingers
}

\author{
RUSTAMAJI' ${ }^{1}$, PAULINE RAHMIATI ${ }^{2}$, SARAH PERMATASARI ${ }^{3}$ \\ 1,2,3Teknik Elektro Institut Teknologi Nasional Bandung \\ Email : rustamaji@itenas.ac.id
}

\begin{abstract}
ABSTRAK
Ketika suatu pesawat terbang mengalami kecelakaan terjatuh ke dalam air, maka lokasi keberadaannya dapat dideteksi oleh alat yang disebut receiver beacon black box locator acoustic (pingers receiver). Pingers receiver berfungsi untuk menerima sinyal dengan frekuensi $37,5 \mathrm{kHz} \pm 1 \mathrm{kHz}$ dari pingers transmitter atau Underwater Locator Beacon (ULB) yang berada pada black box pesawat. Dalam penelitian ini dibuat perancangan pingers receiver yang tersusun dari rangkaian Band Pass Filter (BPF), detektor selubung, penguat audio, dan loud speaker. Frekuensi sinyal $37,5 \mathrm{kHz} \pm 1 \mathrm{kHz}$ yang dikirim oleh pingers transmitter akan diterima oleh pingers receiver, dimana tahap pertama melewati rangkaian Band Pass Filter (BPF) selanjutnya sinyal akan dideteksi oleh detektor selubung untuk mengambil kembali sinyal informasi yang berupa sinyal pulsa dengan lebar pulsa 10 milidetik dan interval 1 detik sebagai sinyal pingers yang nantinya mampu didengar oleh telinga manusia. Berdasarkan perancangan yang telah dibuat, output sinyal yang dihasilkan oleh prototipe pingers receiver tersebut memiliki lebar pulsa 14 milidetik dengan interval 1 detik.
\end{abstract}

Kata kunci: pingers receiver, band pass filter (BPF), detektor selubung, loud speaker.

\begin{abstract}
When an aircraft caught in an accident and crashes into the water, its location can be detected using a device called a receiver beacon black box locator acoustic (pingers receiver). The pingers receiver functioned as a reciever signal with $37,5 \mathrm{kHz} \pm 1 \mathrm{kHz}$ frequency from trnasmitter pingers or Underwater Locator Beacon (ULB) which is on air plane black blox. In this research made design pingers receiver composed of a series of Band Pass Filter (BPF), envelope detector, audio amplifier, and loud speaker. The signal of $37,5 \mathrm{kHz} \pm 1 \mathrm{kHz}$ frequency sent by pingers transmitter will bereceived by pingers receiver, after which the signal will be processed by the Band Pass Filter (BPF) circuit before being detected by envelope detector for take back the signal information which like pulse signal with $10 \mathrm{~ms}$ width and 1 second interval as pingers signal tha can be to be heard by human ear. Based on the design that was made, the signal ouput generated by the prototype has a $14 \mathrm{~ms}$ width with 1 second interval.
\end{abstract}

Keywords: pingers receiver, band pass filter (BPF), envelope detector, loud speaker. 


\section{PENDAHULUAN}

Pada pencarian pesawat terbang yang mengalami kecelakaan di lautan, diperlukan alat yang dapat menentukan atau mendeteksi lokasi keberadaan pesawat terbang tersebut di dalam air. Receiver beacon black box locator acoustic (pingers receiver) dapat digunakan untuk membantu menentukan lokasi keberadaan pesawat terbang. Oleh karena itu pesawat terbang komersil dilengkapi dengan alat Underwater Locator Beacon (ULB) yang tersimpan pada black box, dimana alat ini yang memancarkan sinyal pingers dengan frekuensi $37,5 \mathrm{kHz}$ sebagai penanda (beacon) lokasi keberadaan pesawat terbang (Rustamaji, 2015).

Pingers yang dikirim oleh black box pesawat atau lebih tepatnya dari Underwater Locator Beacon (ULB) akan memancarkan sinyal atau getaran dengan frekuensi $37,5 \mathrm{kHz}$, dimana frekuensi inilah yang dimodulasi oleh sinyal pulsa dengan durasi 10 milidetik dalam interval 1 detik yang dapat diterima pada jarak tertentu oleh pingers receiver (Sutoyo, 2014). Pingers receiver memiliki peran yang sangat penting dalam mendeteksi adanya sinyal yang dibangkitkan oleh pingers. Pingers receiver akan mengeluarkan sinyal "ping" sebagai tanda telah menerima sinyal pingers. Proses dalam penerimaan sinyal pingers hingga mengahasilkan suara "ping" inilah yang akan dibahas pada penelitian ini. Namun pada kondisi aslinya pingers receiver bukanlah sebuah alat yang terbuat dari komponen sederhana dan bukan alat yang mampu dimiliki oleh siapapun, maka pada penelitian ini akan dilakukan perancangan prototipe dan realisasi rangkaian dari pingers receiver dengan komponen yang sederhana untuk menganalisi proses penerimaan sinyal pingers hingga menghasilkan suara "ping".

Penelitian ini bertujuan untuk merancang dan merealisasikan prototipe receiver beacon black box locator acoustic $(37,5 \pm 1) \mathrm{kHz}$ pingers sebagai penerima sinyal pingers.

Dalam pembuatan penelitian ini agar lebih terarah dan jelas penulis membatasi kajian yang akan dibahas, adapun batasan masalahnya adalah prototipe yang dirancang hanya merupakan bagian pingers receiver, prototipe ini tidak menggunakan hydrophone dalam air serta tidak membahas mengenai jarak sebagai penerima sinyalnya sebagaimana alat aslinya, dan pengujian prototipe tidak dilakukan di dalam air tetapi hanya menggunakan osiloskop untuk menampilkan sinyal yang dihasilkan dari pingers receiver serta loud speaker untuk mendengar suara "ping" yang dihasilkan dari prototipe receiver ini.

\section{PERANCANGAN}

\subsection{Pingers receiver}

Pingers receiver berfungsi untuk menerima sinyal dengan frekuensi 37,5 kHz $\pm 1 \mathrm{kHz}$ yang terus aktif selama 30 hari (Donni, 2007). Sinyal on-off keying dari transmitter yang berada pada black box pesawat atau biasa disebut Underwater Locator Beacon (ULB) diterima oleh pingers receiver (Rustamaji, 2015). Pada perancangan pingers receiver ini dibagi menjadi beberapa sub pokok pembahasan meliputi perancangan rangkaian Band Pass Filter (BPF), rangkaian detektor selubung, dan penggabungan dari seluruh rangkaian prototipe receiver beacon black box locator acoustic yang terdiri dari rangkaian Band Pass Filter (BPF) dan rangkaian detektor selubung yang dihubungkan dengan penguat audio OpAmp LM741 serta loud speaker. Berikut adalah rancangan dari rangkaian pingers receiver yang akan diimplementasikan ditampilkan pada Gambar 1. 


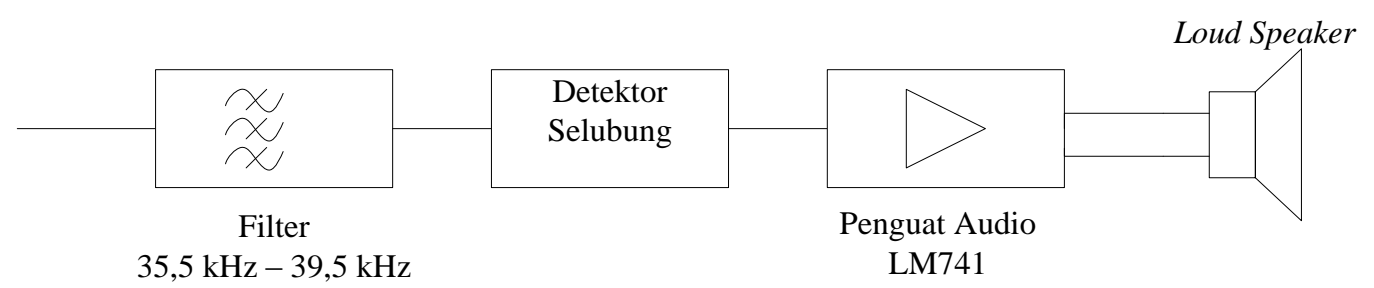

Gambar 1. Diagram Blok Prototipe Receiver Beacon Black Box Locator Acoustic

Gambar 1 menunjukkan tahapan dalam perancangan rangkaian pingers receiver. Dimulai dengan perancangan rangkaian Band Pass Filter (BPF), dilanjutkan dengan perancangan rangkaian detektor selubung yang nanti diinginkan bentuk output sinyalnya berbentuk sinyal pulsa dengan lebar pulsa 10 milidetik dan interval 1 detik. Sinyal output dari rangkaian detektor selubung akan dinaikkan nilai tegangannya dengan penguat audio LM741 agar loud speaker mampu merespon baik sinyal yang diterimanya.

Terdapat beberapa spesifikasi yang harus diperhatikan dalam merancang prototipe receiver beacon black box locator acoustic diantaranya :

1. Mampu mendeteksi (menerima) sinyal dengan frekuensi $(37,5 \pm 1) \mathrm{kHz}$ (User's Manual, 2011).

2. Memiliki rentang frekuensi $35,5 \mathrm{kHz}-39,5 \mathrm{kHz}$ sebagai lebar pita (bandwidth) dalam merancang BPF.

3. Memiliki lebar pulsa 10 milidetik (User's Manual, 2011).

4. Menggunakan power supply DC 12 volt.

5. Op-amp yang digunakan menggunakan kode LM741.

6. Jenis dioda yang digunakan adalah jenis diode detektor dengan kode 1N60.

\subsubsection{Rangkaian Band Pass Filter (BPF)}

Filter yang digunakan dalam prototipe ini menggunakan jenis Band Pass Filter (BPF), dimana frekuensi sinyal yang dipilih berada pada frekuensi $37,5 \mathrm{kHz}$ dengan rentang frekuensi $35,5 \mathrm{kHz}-39,5 \mathrm{kHz}$. Rangkaian BPF yang digunakan menggunakan rangkaian filter aktif. Rangkaian BPF yang dirancang seperti pada Gambar 2.

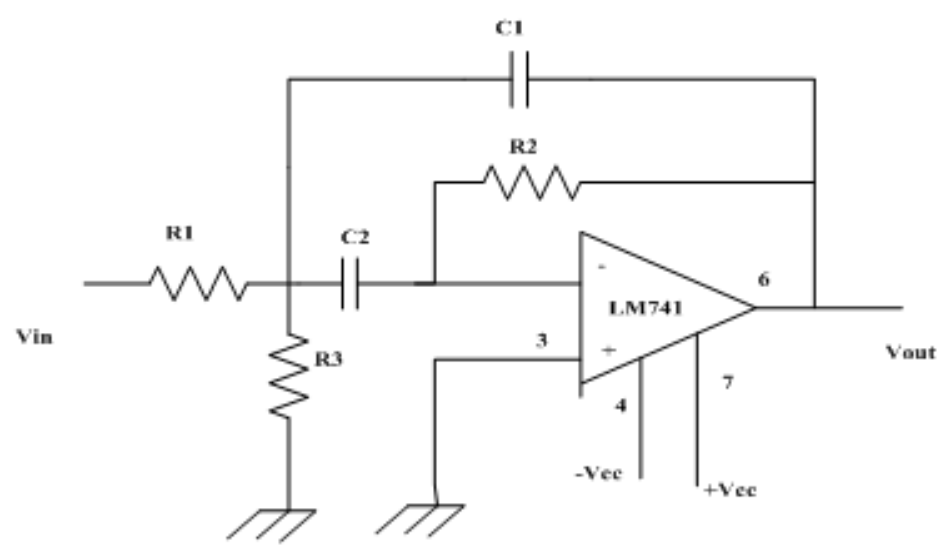

Gambar 2. Rancangan Rangkaian BPF 
Untuk sinyal pingers $37,5 \mathrm{kHz}$ dengan rentang frekuensi $35,5 \mathrm{kHz}-39,5 \mathrm{kHz}$ memiliki $B W=4 \mathrm{kHz}=25,133 \mathrm{krad} / \mathrm{s}$. Bila dianggap nilai $C_{1}=C_{2}=C$, dapat dihitung nilai $R_{1}, R_{2}$, dan $R_{3}$ sebagai berikut :

$$
\begin{aligned}
& \mathrm{R}_{2}=\frac{2}{(B W \times C)} \\
& \mathrm{R}_{1}=\frac{1}{2} \mathrm{R}_{2} \\
& \mathrm{R}_{3}=\frac{\mathrm{R}_{2}}{\left(4 \mathrm{Q}^{2}-2\right)}
\end{aligned}
$$

Dimana $\mathrm{f}_{\mathrm{o}}=37,5 \mathrm{kHz}=235,62 \mathrm{krad} / \mathrm{s}$

Dan $\mathrm{C}=0,01 \mu \mathrm{F}$

Maka didapatkan nilai R seperti berikut :

$$
\begin{aligned}
& \mathrm{R}_{2}=\frac{2}{(\mathrm{BW} \times \mathrm{C})}=\frac{2}{\left(25,133 \times(0,01) \times 10^{-6}\right)}=7,95766 \mathrm{k} \Omega \\
& \mathrm{R}_{1}=\frac{1}{2} \mathrm{R}_{2}=\frac{1}{2}(7,95766)=3,97883 \mathrm{k} \Omega \\
& \mathrm{R}_{3}=\frac{\mathrm{R}_{2}}{\left(4 \mathrm{Q}^{2}-2\right)}=\frac{7,95766 \mathrm{k} \Omega}{\left(4 \mathrm{Q}^{2}-2\right)} \\
& \mathrm{Q}=\frac{\mathrm{f}_{\mathrm{o}}}{\mathrm{BW}}=\frac{37,5 \mathrm{kHz}}{4 \mathrm{kHz}}=9,375 \\
& \mathrm{R}_{3}=\frac{7,95766 \mathrm{k} \Omega}{\left(4 \mathrm{Q}^{2}-2\right)}=\frac{7,95766 \mathrm{k} \Omega}{\left(4.9,375^{2}-2\right)}=22,765 \Omega
\end{aligned}
$$

Jadi nilai - nilai resistor yang digunakan adalah :

$\mathrm{R}_{1}=3,97883 \mathrm{k} \Omega ; \mathrm{R}_{2}=7,95766 \mathrm{k} \Omega ; \mathrm{R}_{3}=22,765 \Omega$

\subsubsection{Rangkaian Detektor Selubung}

Proses deteksi selubung terdiri dari dua tahap :

1. Rectifiying (penyearahan) gelombang yang datang menggunakan rangkaian penyearah dioda.

2. Filtering (perataan) hasil penyearahan dengan Low Pass Filter (LPF), untuk menghilangkan komponen frekuensi tinggi dari sinyal.

Dalam merancang sebuah detektor selubung membutuhkan sebuah dioda dengan jenis dioda detektor. Dioda detektor ini akan disambungkan dengan rangkaian Low Pass Filter (LPF) seperti rangkaian yang terlihat pada Gambar 3. 


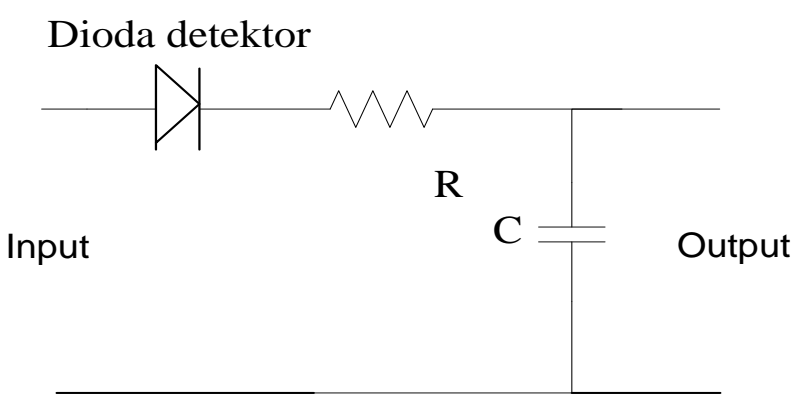

\section{Gambar 3. Rancangan Rangkaian Detektor Selubung}

Dioda detektor yang digunakan dalam rancangan ini menggunakan kode 1N60. Dioda disini berfungsi sebagai penyearah, dimana output sinyal dioda hanya berupa bagian positip saja. Selanjutnya bagian positip dari output dioda akan diratakan oleh Low Pass Filter (LPF) dan untuk mendapatkan perataan yang baik maka frekuensi cut - off dari LPF harus cukup rendah.

Untuk mengetahui nilai frekuensi cut - off yang diinginkan sebagai rancangan LPF pada detektor selubung dapat dilihat pada Gambar 4.

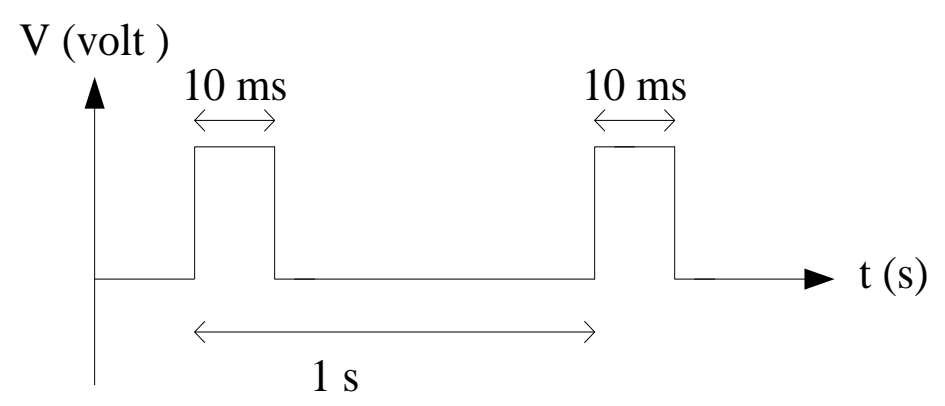

Gambar 4. Bentuk Sinyal Output Detektor Selubung

Dari Gambar 4 dapat terlihat bahwa lebar pulsa yang diinginkan 10 milidetik dan frekuensi cut - off $=100 \mathrm{~Hz}$. Dengan mengacu pada nilai frekuensi $c u t$ - off tersebut maka dapat dihitung nilai $\mathrm{R}$ dengan perumusan sebagai berikut :

$$
\mathrm{f}_{\text {cut }- \text { off }}=\frac{1}{(2 \pi R C)}
$$

Dimana nilai C yang kita tetapkan $0.01 \mu F$

$\mathrm{f}_{\text {cut }- \text { off }}=\frac{1}{(2 \pi R C)}=\frac{1}{\left(2 \pi R 0,01 \times 10^{-6}\right)}$

maka $\mathrm{R}=159,154 \mathrm{k} \Omega$

\subsubsection{Penggabungan Rancangan Prototipe Receiver Beacon Black Box Locator}

Setelah menghitung seluruh nilai komponen yang dibutuhkan untuk merancang receiver beacon black box locator maka rangkaian filter BPF dan detektor selubung yang telah terhubung selanjutnya dihubungkan dengan rangkaian penguat audio yang menggunakan 
LM741 serta loud speaker. Rangkaian penguat audio dibutuhkan untuk memenuhi batasan tegangan dari loud speaker apabila dperlukan. Untuk penguat audio LM741 pada rangkaian filter BPF ataupun pada rangkaian penguat audio yang akan dihubungkan dengan loud speaker sama - sama menggunakan nilai tegangan power supply DC 12 volt. Untuk rangkaian penguat audio yang akan dihubungkan dengan loud speaker memiliki rancangan rangkaian seperti yang terlihat pada Gambar 5.

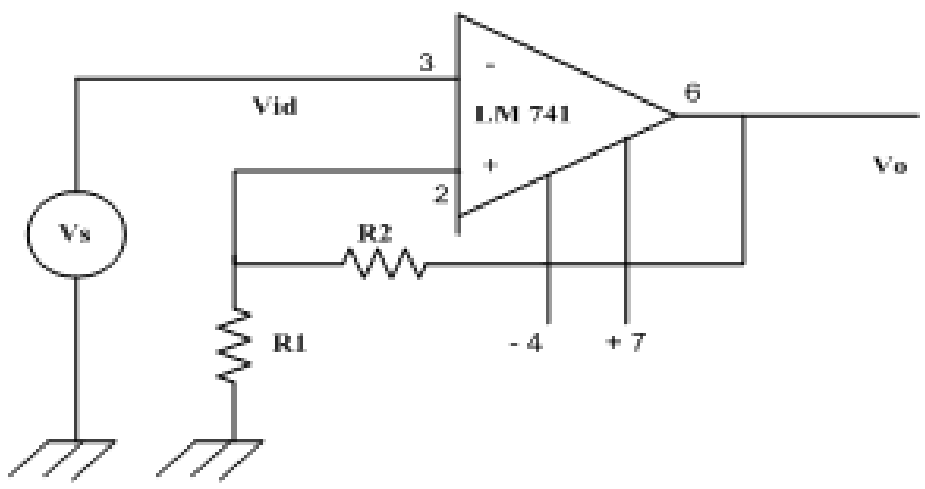

Gambar 5. Rangkaian Penguat Audio

Rangkaian penguat audio (non-inverting), seperti yang ditunjukkan pada Gambar 5, berfungsi untuk menaikkan nilai tegangan dari output rangkaian detektor selubung. Dalam menaikkan nilai tegangan ini menggunakan perumusan sebagai berikut untuk mendapatkan nilai komponen $\mathrm{R}$ yang dibutuhkan (Bruce, 2001).

$$
V_{o}=1+\left[\frac{R_{2}}{R_{1}} \cdot V_{i d}\right]
$$

Dimana nilai $V_{o}=7,5 V_{p-p}$ dan nilai $R_{1}$ yang diinginkan adalah $R_{1}=1 \mathrm{k} \Omega$. Bila nilai $V_{\text {id }}=0,8$ $\mathrm{V}_{\mathrm{p}-\mathrm{p}}$, maka nilai $\mathrm{R}_{2}=6,5 \mathrm{k} \Omega$

Setelah rangkaian penguat audio dirangkai, selanjutnya dilakukan penggabungan rangkaian prototipe receiver beacon black box locator acoustic secara keseluruhan. Penggabungan ini terdiri dari rangkaian BPF, rangkaian detektor selubung, rangkaian penguat audio, dan loud speaker. Penggabungan ini seperti yang terlihat pada Gambar 6.

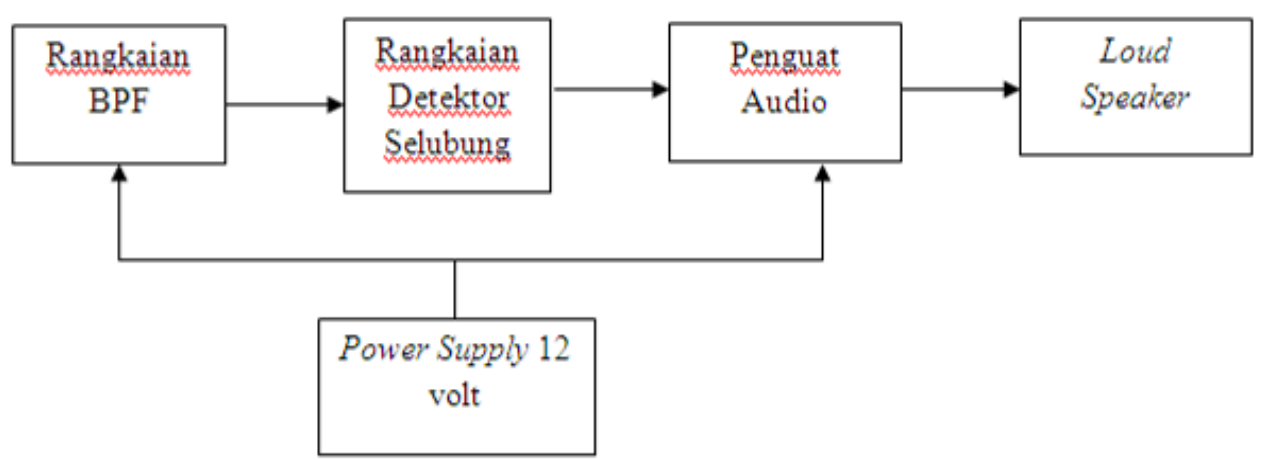

Gambar 6. Diagram Blok Rangkaian Keseluruhan Prototipe Receiver Beacon Black Box Locator Acoustic 


\section{PENGUKURAN DAN ANALISIS}

\subsection{Pengukuran pada Band Pass Filter (BPF)}

Rangkaian Band Pass Filter (BPF) yang sebelumnya telah dirancang selanjutnya dilakukan pengukuran untuk melihat kesesuaian antara sinyal output dengan spesifikasi yang diinginkan menggunakan osiloskop.

Spesifikasi yang diinginkan sebagai berikut :

1. Mampu mendeteksi (menerima) sinyal dengan frekuensi $(37,5 \pm 1) \mathrm{kHz}$.

2. Memiliki rentang frekuensi $35,5 \mathrm{kHz}-39,5 \mathrm{kHz}$ sebagai lebar pita (bandwidth) dalam merancang BPF.

Alat - alat yang diperlukan untuk mengukur rangkaian BPF adalah rangkaian transmitter beacon black box, audio generator, power supply DC 12 volt, dan osiloskop digital. Pengukuran rangkaian BPF yang pertama tanpa menggunakan rangkaian transmitter beacon black box seperti yang terlihat pada Gambar 7.

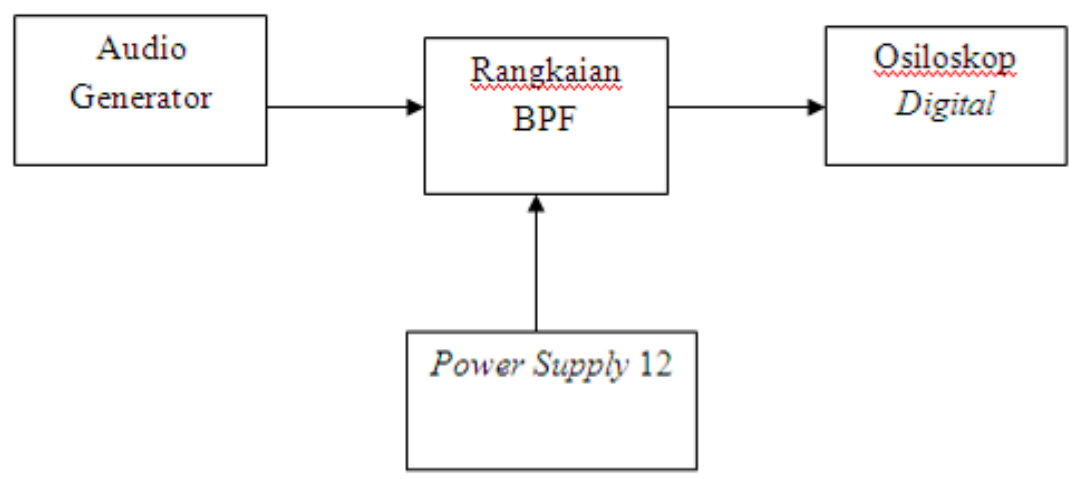

\section{Gambar 7. Diagram Blok Pengukuran Pertama Rangkaian Band Pass Filter}

Pengukuran pertama ini dilakukan untuk mengukur nilai tegangan dan frekuensi tertinggi yang didapatkan apakah sudah sesuai dengan yang diinginkan yaitu pada frekuensi 37,5 $\mathrm{kHz}$. Pada pengukuran ini audio generator berfungsi untuk memberikan tegangan input pada rangkaian BPF dan sebagai input frekuensi yang diinginkan, power supply berfungsi untuk mengaktifkan op-amp, dan osiloskop berfungsi untuk melihat bentuk sinyal output dar rangkaian BPF serta mengetahui nilai tegangan tertinggi dari sinyal output BPF pada frekuensi yang diinginkan.

Berikut hasil pengukuran nilai tegangan sinyal output yang didapatkan dengan variasi besarnya frekuensi sinyal input dari audio generator serta Gambar grafik dari respon frekuensi yang diukur. 
Tabel 1. Nilai Sinyal Output Rangkaian BPF Setiap Kenaikan 0,5 kHz

\begin{tabular}{|c|c|c|}
\hline $\begin{array}{c}\text { Tegangan } \\
\text { input } \\
\left(V_{p-p}\right)\end{array}$ & $\begin{array}{l}\text { Frekuensi } \\
\quad(\mathbf{k H z})\end{array}$ & $\begin{array}{c}\text { Tegangan } \\
\text { output } \\
\left(\mathrm{V}_{\mathrm{p}-\mathrm{p}}\right)\end{array}$ \\
\hline 5,08 & 25 & 0,432 \\
\hline 5,08 & 25,5 & 0,448 \\
\hline 5,08 & 26 & 0,496 \\
\hline 5,08 & 26,5 & 0,504 \\
\hline 5,08 & 27 & 0,524 \\
\hline 5,08 & 27,5 & 0,552 \\
\hline 5,08 & 28 & 0,556 \\
\hline 5,08 & 28,5 & 0,624 \\
\hline 5,08 & 29 & 0,648 \\
\hline 5,08 & 29,5 & 0,656 \\
\hline 5,08 & 30 & 0,712 \\
\hline 5,08 & 30,5 & 0,776 \\
\hline 5,08 & 31 & 0,824 \\
\hline 5,08 & 31,5 & 0,872 \\
\hline 5,08 & 32 & 0,976 \\
\hline 5,08 & 32,5 & 1,04 \\
\hline 5,08 & 33 & 1,14 \\
\hline 5,08 & 33,5 & 1,32 \\
\hline 5,08 & 34 & 1,28 \\
\hline 5,08 & 34,5 & 1,56 \\
\hline 5,08 & 35 & 1,96 \\
\hline 5,08 & 35,5 & 2,44 \\
\hline 5,08 & 36 & 4,52 \\
\hline 5,08 & 36,5 & 4,32 \\
\hline 5,08 & 37 & 4,04 \\
\hline 5,08 & 37,5 & 3,8 \\
\hline 5,08 & 38 & 3,76 \\
\hline 5,08 & 38,5 & 3,4 \\
\hline 5,08 & 39 & 3,24 \\
\hline 5,08 & 39,5 & 3,08 \\
\hline 5,08 & 40 & 2,96 \\
\hline 5,08 & 40,5 & 2,52 \\
\hline 5,08 & 41 & 2,36 \\
\hline 5,08 & 41,5 & 2,24 \\
\hline 5,08 & 42 & 2,12 \\
\hline 5,08 & 42,5 & 1,88 \\
\hline 5,08 & 43 & 1,76 \\
\hline
\end{tabular}




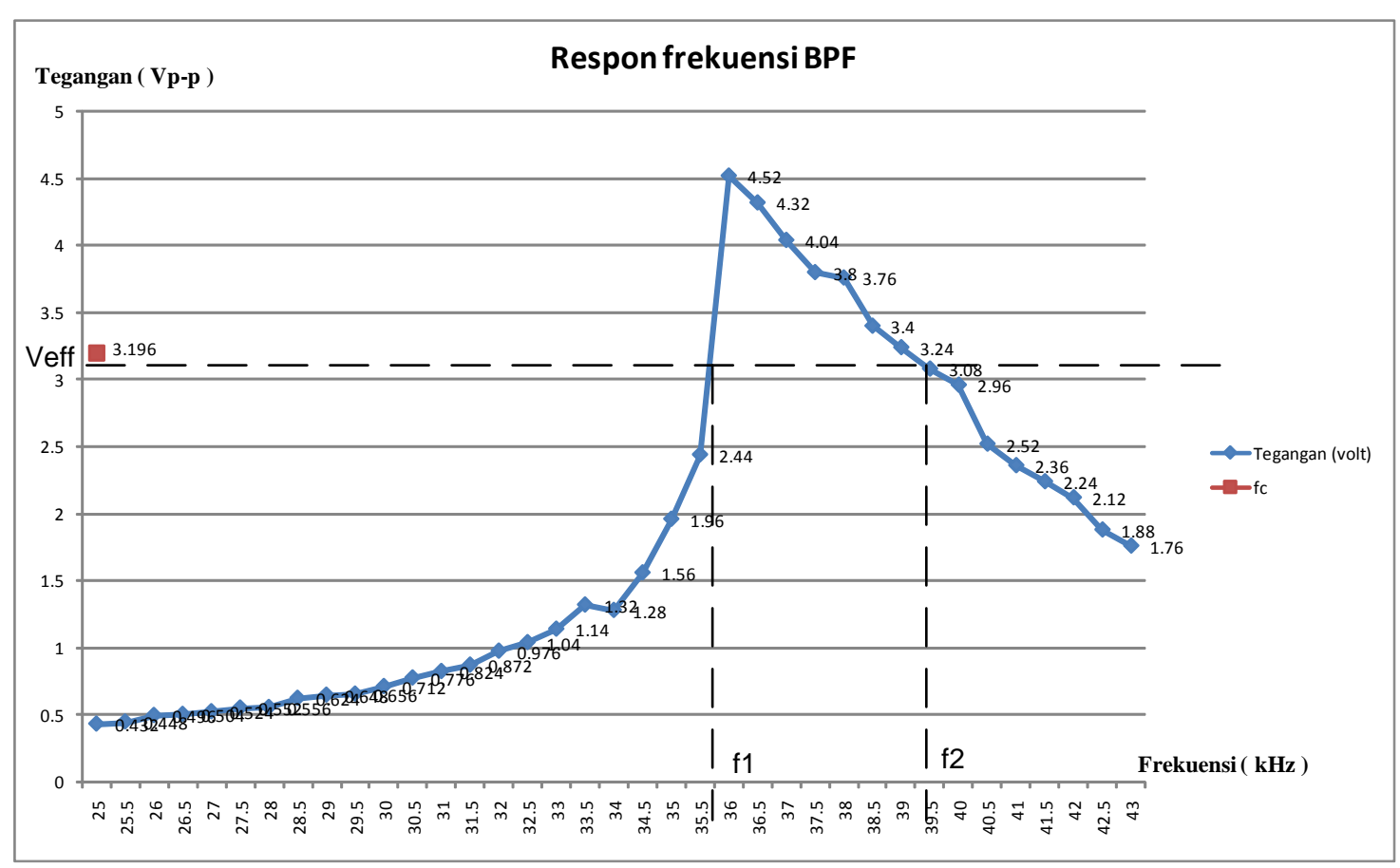

Gambar 8. Grafik Respon Frekuensi BPF

Respon frekuensi filter hasil rancangan memiliki karakteristik yang sesuai dengan respon frekuensi BPF sesuai dengan target filter yang diperlukan, dimana memiliki nilai-nilai seperti yang terlihat pada Tabel 2 .

Tabel 2. Nilai Respon Frekuensi BPF

\begin{tabular}{|c|c|}
\hline $\mathbf{f}_{\mathbf{o}}$ & $36 \mathrm{kHz}$ \\
\hline $\mathbf{V}_{\text {maksimum }}$ & $4,52 \mathrm{~V}_{\mathrm{p}-\mathrm{p}}$ \\
\hline $\mathbf{V}_{\text {eff }}$ & $3,196 \mathrm{~V}_{\mathrm{p}-\mathrm{p}}$ \\
\hline $\mathbf{f}_{\mathbf{1}}$ & $35,5 \mathrm{kHz}$ \\
\hline $\mathbf{f}_{\mathbf{2}}$ & $39,2 \mathrm{kHz}$ \\
\hline
\end{tabular}

Pada grafik respon frekuensi BPF, nilai $V_{\text {eff }}$ juga adalah sebagai nilai tegangan untuk $f_{1}$ dan $f_{2}$.

Pada rangkaian BPF ini tidak medapatkan nilai tegangan maksimum pada frekuensi $37,5 \mathrm{kHz}$ melainkan pada frekuensi $36 \mathrm{kHz}$, namun nilai yang didapatkan ini masih berada pada rentang frekuensi BPF yang diinginkan yaitu berada pada nilai $35,5 \mathrm{kHz}-39,5 \mathrm{kHz}$. Hal ini terjadi karena beberapa faktor, salah satunya nilai - nilai komponen yang tidak seluruhnya tepat sesuai dengan perhitungan. Dalam merealisasikan rangkaian BPF ini nilai komponen yang dipakai sebagai berikut :

Tabel 3. Nilai Komponen Pada Rangkaian BPF

\begin{tabular}{|c|c|}
\hline R1 & $3978 \Omega$ \\
\hline R2 & $6600 \Omega$ \\
\hline R3 & $22 \Omega$ \\
\hline C1 & $1,19 \mathrm{pF}$ \\
\hline C2 & $2 \mathrm{pF}$ \\
\hline
\end{tabular}


Pada rangkaian BPF nilai komponen kapasitor C1 dan C2 sangat berpengaruh pada perubahan nilai tegangan output dan frekuensi tertinggi yang didapatkan. Apabila nilai $\mathrm{C} 1$ dan C2 tidak tepat, maka frekuensi yang didapatkan tidak sampai ke nilai $37,5 \mathrm{kHz}$ melainkan berada pada nilai sekitar $27 \mathrm{kHz}$, sehingga nilai $\mathrm{C}$ ini harus diatur sedemikian rupa hingga mendapatkan nilai tegangan maksimum pada frekuensi $35,5 \mathrm{kHz}-39,5 \mathrm{kHz}$. Selain nilai C, nilai R2 juga mempengaruhi nilai frekuensi tertinggi yang diinginkan.

Setelah mengetahui nilai tegangan maksimum yang didapatkan berada pada rentang frekuensi yang diinginkan, selanjutnya pengukuran yang kedua dilakukan dengan menghubungkan rangkaian pada pengukuran pertama ke rangkaian transmitter beacon black box (pingers transmitter) seperti yang terlihat pada diagram blok Gambar 9.

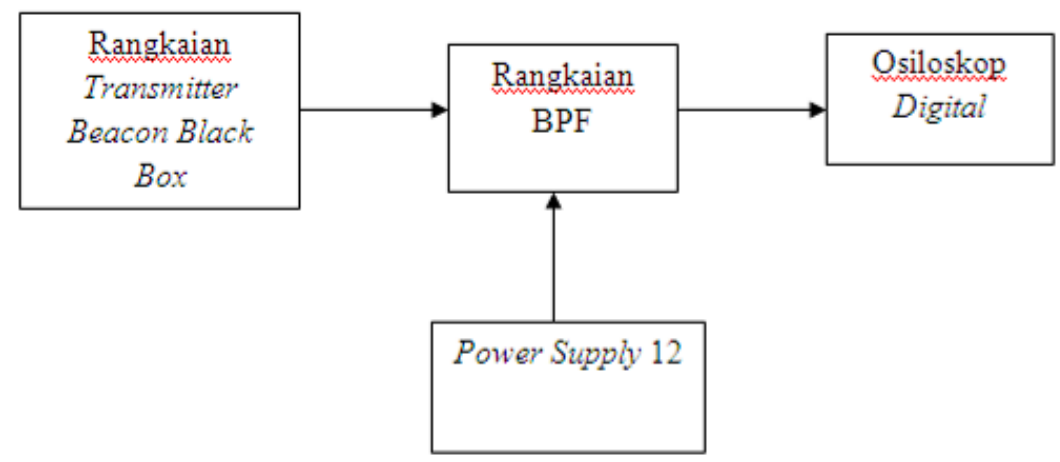

Gambar 9. Diagram Blok Pengukuran Kedua Rangkaian BPF

Pengukuran ini dilakukan untuk mengetahui bentuk sinyal output setelah dihubungkan dengan rangkaian transmitter beacon black box (pingers transmitter) dan mengukur nilai tegangan output serta frekuensinya. Realisasi rangkaian BPF dan bentuk sinyal input serta output yang didapatkan pada pengukuran ini seperti yang terlihat pada Gambar 10, 11, dan 12.

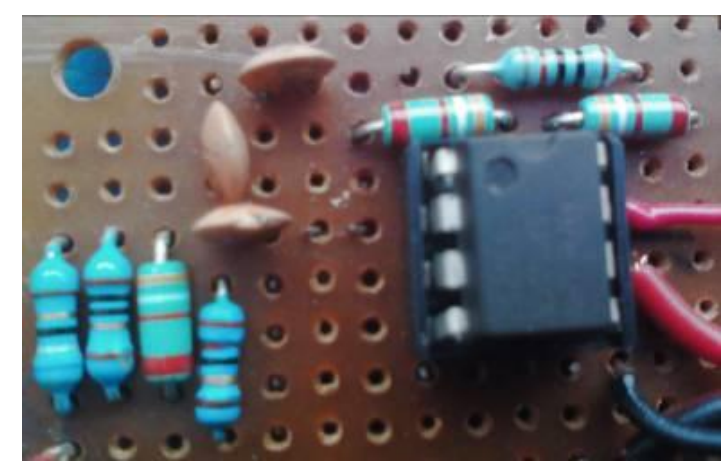

Gambar 10. Realisasi Rangkaian BPF 


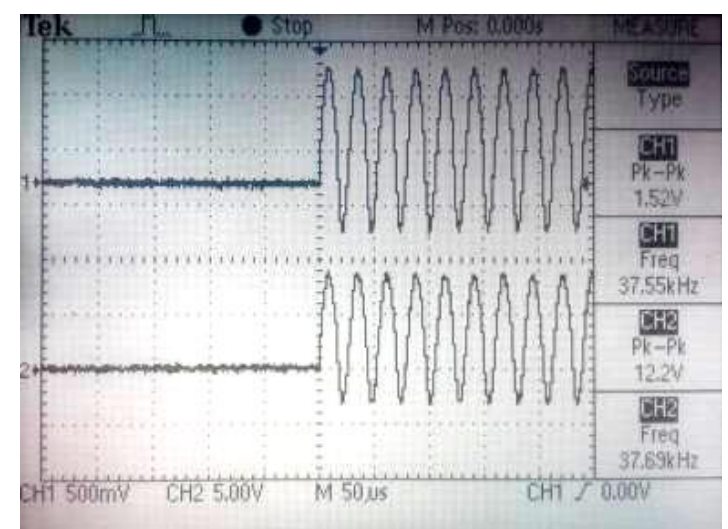

Gambar 11. Sinyal Input dari Transmitter Beacon Black Box (CH 2)

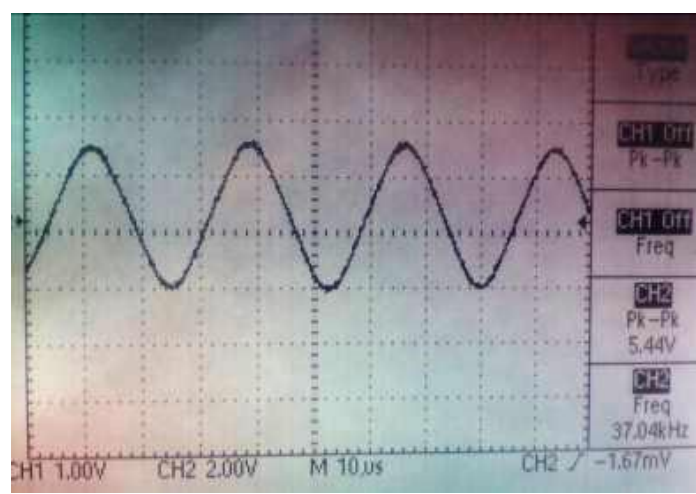

Gambar 12. Sinyal Output Rangkaian BPF Setelah Dihubungkan Dengan Rangkaian Transmitter Beacon Black Box

Hasil pengukuran sinyal output rangkaian BPF setelah dihubungkan dengan transmitter beacon locator black box terlihat pada Tabel 4.

Tabel 4. Hasil Pengukuran Sinyal Output Rangkaian BPF Setelah Dihubungkan Dengan Transmitter Beacon Black Box

\begin{tabular}{|c|c|}
\hline $\begin{array}{c}\text { Tegangan Output } \\
\left(\mathbf{V}_{\mathbf{p}-\mathbf{p}}\right)\end{array}$ & $\begin{array}{c}\text { Frekuensi } \\
(\mathbf{k H z})\end{array}$ \\
\hline 5,44 & 37,04 \\
\hline
\end{tabular}

Dari Tabel 4 dapat diketahui bahwa rangkaian BPF masih dapat dikatakan berfungsi dengan baik karena nilai frekuensi yang didapatkan masih berada pada rentang frekuensi yang diinginkan. Nilai rentang frekuensi yang diinginkan masih berada pada $35,5 \mathrm{kHz}-39,5 \mathrm{kHz}$. Hal ini menunjukkan bahwa rangkaian BPF ini masih mampu menerima sinyal output dari rangkaian transmitter beacon black box yang memiliki nilai frekuensi $37,5 \mathrm{kHz}$.

\subsection{Pengukuran Rangkaian Detektor Selubung}

Untuk mengukur sinyal output dari rangkaian detektor selubung ini rangkaian perlu dihubungkan dengan rangkaian transmitter beacon black box serta rangkaian BPF seperti pada diagram blok Gambar 13. 


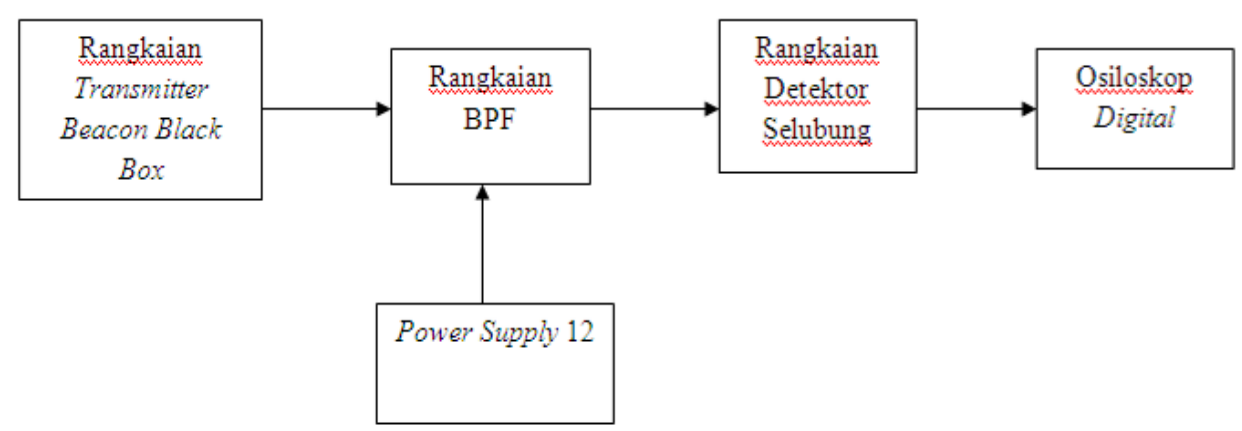

Gambar 13. Diagram Blok Pengujian Rangkaian Detektor Selubung

Sebelum mengukur sinyal output dari detektor selubung dilakukan pengukuran sinyal output pada komponen dioda detektor terlebih dahulu. Hasil sinyal output dari komponen dioda detektor setelah dihubungkan dengan transmitter beacon black box dan rangkaian BPF seperti yang terlihat pada Gambar 14.

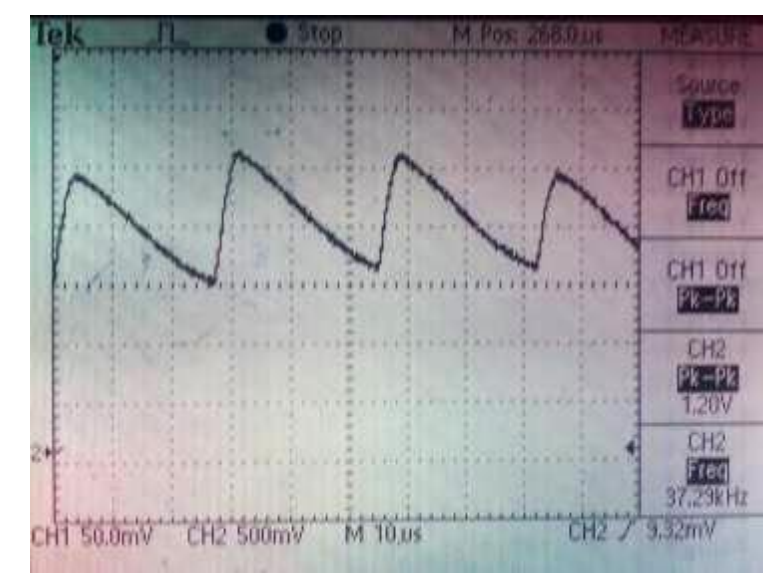

Gambar 14. Output Sinyal Dioda Detektor

Setelah melihat bentuk sinyal output dari komponen dioda detektor yang dihubungkan dengan rangkaian transmitter beacon black box dan rangkaian BPF selanjutnya mengukur nilai output dari rangkaian detektor selubung secara keseluruhan. Realisasi rangkaian detektor selubung dan hasil pengukurannya seperti yang terlihat pada Gambar 15, 16 (a) dan 16 (b).

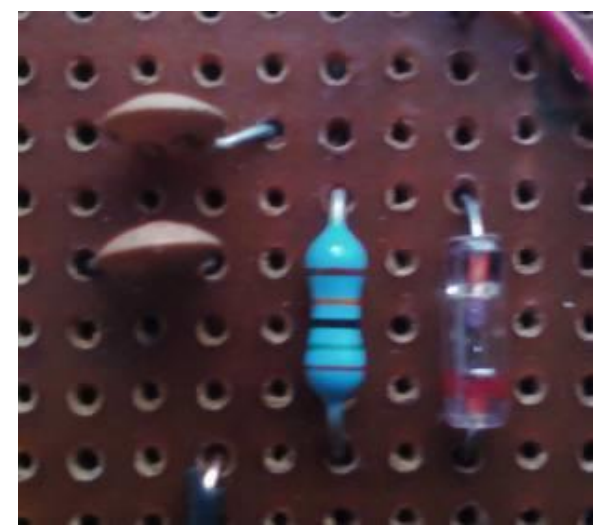

Gambar 15. Realisasi Rangkaian Detektor Selubung 


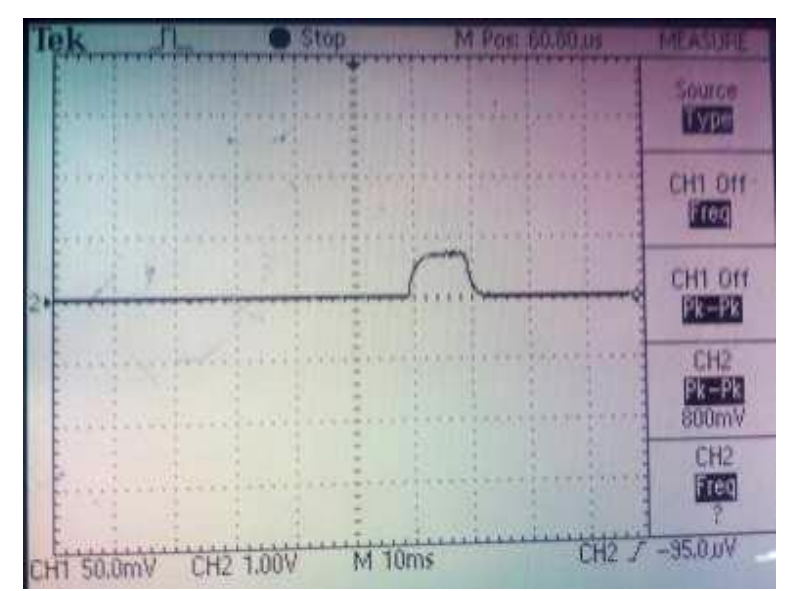

Gambar 16 (a). Sinyal Output Detektor Selubung yang Diperoleh Dengan Lebar Pulsa 12 milidetik

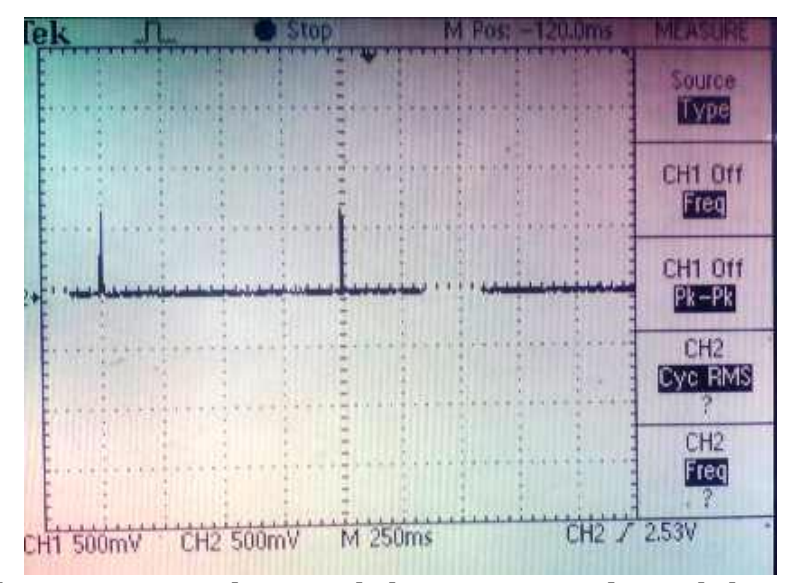

Gambar 16 (b). Sinyal Output Detektor Selubung yang Diperoleh Dengan Interval1 detik

Tabel 5. Hasil Pengukuran Sinyal Output Rangkaian Detektor Selubung Setelah Dihubungkan Dengan Rangkaian Transmitter beacon black box dan Rangkaian BPF

\begin{tabular}{|c|c|c|}
\hline $\begin{array}{c}\text { Tegangan Output } \\
\left(\mathbf{m V}_{\mathbf{p}-\mathbf{p}}\right)\end{array}$ & $\begin{array}{c}\text { Lebar pulsa } \\
\text { (milidetik) }\end{array}$ & $\begin{array}{c}\text { Interval sinyal } \\
\text { (detik) }\end{array}$ \\
\hline 800 & 12 & 1 \\
\hline
\end{tabular}

Pada Gambar 16 (a) dan 16 (b) terlihat bahwa bentuk sinyal output dari rangkaian detektor selubung yang diperoleh hampir serupa dengan bentuk sinyal output yang diinginkan yaitu hampir berbentuk sinyal pulsa dan memiliki nilai interval sinyal yang serupa dengan kriteria sinyal output yang diinginkan yaitu 1 detik. Bentuk sinyal output yang tidak benar - benar tepat seperti bentuk pulsa ini sangat dipengaruhi oleh nilai komponen kapasitor dan resistor sebagai komponen rangkaian Low Pass Filter (LPF) yang berada pada rangkaian detektor selubung. Pada rangkaian detektor selubung ini nilai komponen yang digunakan seperti yang terlihat pada Tabel 6. 


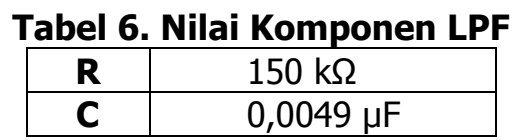

Pada rangkaian detektor selubung ini, sinyal yang tadinya masih berbentuk sinusoida hanya mendapatkan bentuk sinyal positifnya saja setelah sinyal masuk ke komponen dioda detektor. Hal ini dikarenakan sifat dioda detektor yang berfungsi untuk menyearahkan sinyal dengan mendeteksi sinyal pada daerah frekuensi tinggi. Setelah sinyal melewati komponen dioda selanjutnya masuk ke rangkaian LPF untuk meloloskan sinyal pada frekuensi yang rendah saja, dan akhrinya terbentuklah sinyal output yang hampir berbentuk sinyal pulsa.

\subsection{Pengukuran Dari Penggabungan Seluruh Rangkaian Receiver Beacon Balck Box Locator Acoustic}

Setelah mendapatkan hasil pengukuran dari rangkaian BPF dan detektor selubung selanjutnya pengukuran dilakukan dengan menggabungkan dua rangkaian terebut dengan transmitter beacon black box , penguat audio dan loud speaker agar suara dari sinyal output receiver beacon black box mampu didengar oleh telinga manusia dengan jelas. Pengukuran ini dilakukan seperti yang terlihat pada diagram blok Gambar 17.

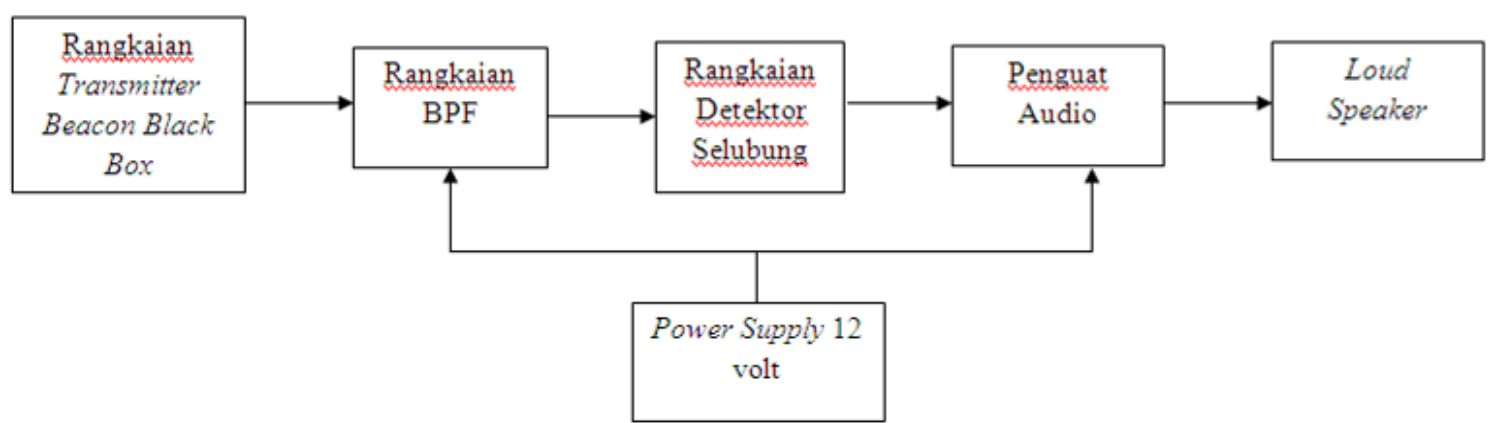

Gambar 17. Diagram Blok Pengukuran Dari Penggabungan Seluruh Rangkaian

Sebelum menghubungkan seluruh rangkaian dengan loud speaker, rangkaian dihubungkan terlebih dahulu dengan penguat audio. Penguat audio ini berfungsi untuk menaikkan nilai tegangan output dari detektor selubung. Realisasi rangkaian penguat audio terlihat pada Gambar 18 dan bentuk sinyal output dari penguat audio terlihat pada Gambar 19 (a) dan 19 (b).

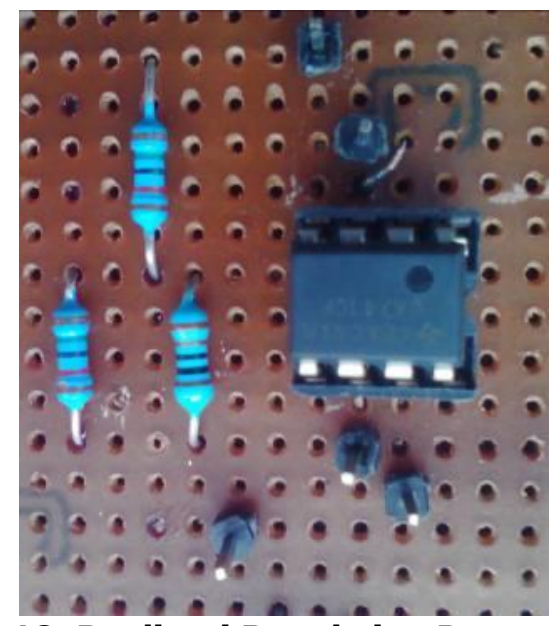

Gambar 18. Realisasi Rangkaian Penguat Audio. 


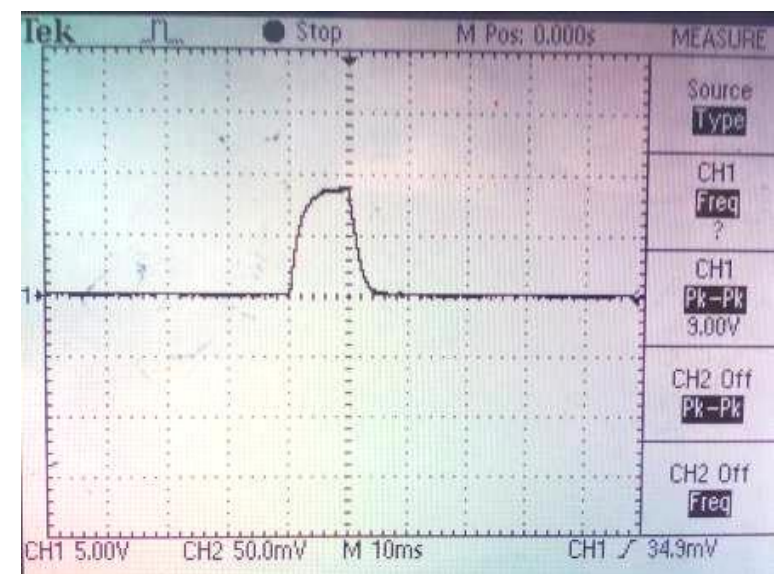

\section{Gambar 19 (a). Bentuk Sinyal Output dari Penguat Audio}

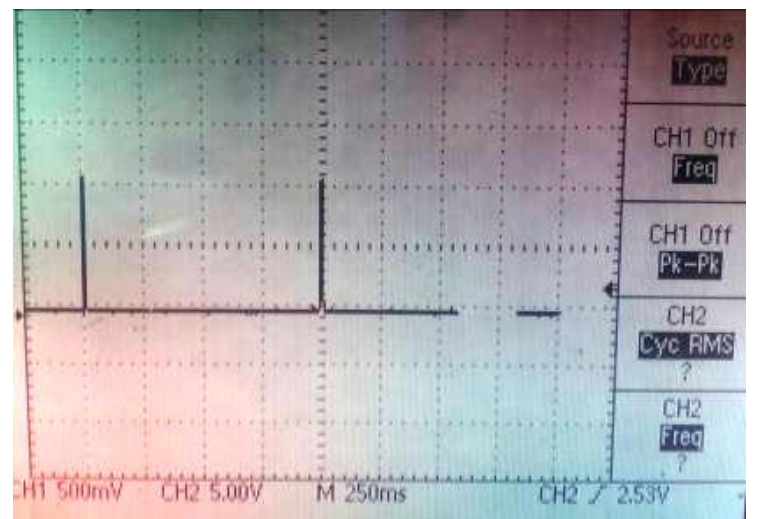

Gambar 19 (b). Sinyal Output dari Penguat Audio

Tabel 7. Hasil Pengukuran Sinyal Output Penguat Audio
\begin{tabular}{|c|c|c|}
\hline $\begin{array}{c}\text { Tegangan } \\
\text { Output }\left(\mathrm{V}_{\mathbf{p}-\mathbf{p}}\right)\end{array}$ & $\begin{array}{c}\text { Lebar pulsa } \\
\text { (milidetik) }\end{array}$ & $\begin{array}{c}\text { Intervalsinyal } \\
\text { (detik) }\end{array}$ \\
\hline 9 & 14 & 1 \\
\hline
\end{tabular}

Bentuk sinyal output penguat audio setelah dihubungkan dengan rangkaian transmitter beacon black box, rangkaian BPF, dan detektor selubung tidak terlalu berbeda dengan bentuk sinyal output rangkaian detektor selubung. Tidak terlalu berbedanya bentuk sinyal ini karena penguat audio hanya berfungsi untuk menaikkan nilai tegangan. Nilai tegangan output yang dihasilkan menjadi $9 \mathrm{Vp}$-p. Semula nilai tegangan hanya akan dinaikkan hingga mencapai 7,5 Vp-p, namun setelah pengukuran mendapatkan hasil yang berbeda. Perbedaan nilai tegangan yang didapatkan dengan nilai tegangan yang diinginkan dipengaruhi oleh nilai komponen resistor yang digunakan pada rangkaian.

Nilai tegangan output dari penguat audio ini diperlukan untuk menggerakkan loud speaker yang nantinya akan diuji secara keseluruhan dengan menghubungkannya pada rangkaian transmitter beacon black box, rangkaian BPF, rangkaian detektor selubung, dan rangkaian penguat audio. Realisasi pengujian akhir ini terlihat pada Gambar 20 dengan menguji pada loud speaker.

Pada pengujian ini loud speaker yang digunakan diganti dengan buzzer, hal ini dikarenakan suara yang terdengar dari lebih jelas dibandingkan suara yang dihasilkan dari loud speaker. 


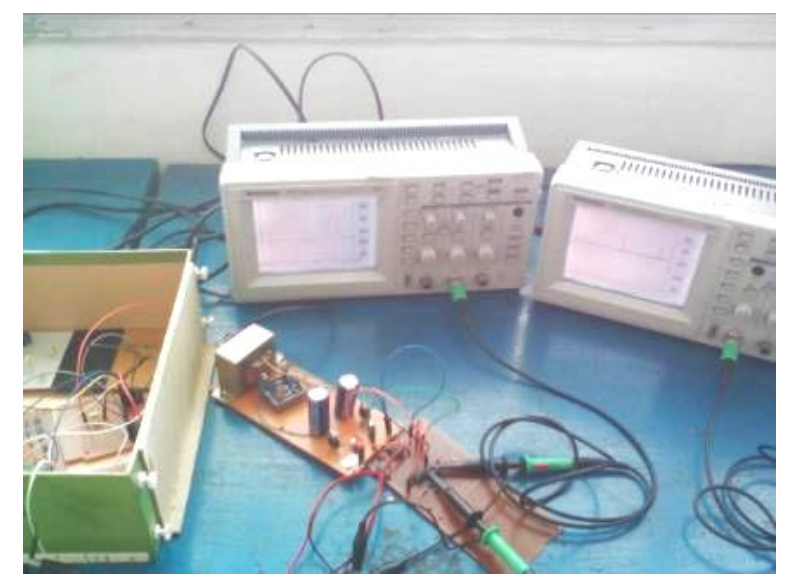

Gambar 20. Pengujian Akhir Receiver Beacon Black Box Locator Acoustic

Pada pengujian akhir ini suara terdengar dengan sangat jelas dan ketika buzzer menghasilkan suara maka sinyal akan terlihat pada osiloskop dan ketika suara tidak terdengar maka sinyal akan diredam. Suara ini terdengar dalam selang 1 detik sesuai dengan nilai interval sinyal yang didapatkan yaitu 1 detik. Untuk realisasi seluruh rangkaian receiver beacon black box locator terlihat pada Gambar 21.

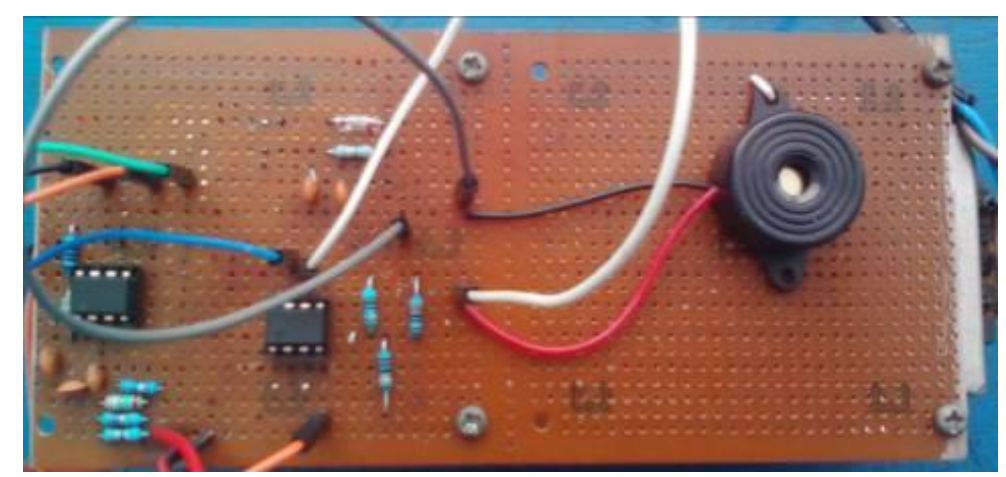

Gambar 21. Realisasi Keseluruhan Rangkaian Prototipe Receiver Beacon Black Box Locator Acoustic

\section{KESIMPULAN}

Dari hasil pengukuran dan analisis dapat ditarik kesimpulan bahwa :

1. Rangkaian Band Pass Filter (BPF) yang telah dirancang mampu melewatkan sinyal pada range frekuensi 35,5 kHz - 39,5 kHz yang berasal dari transmitter beacon black box.

2. Sinyal output dari rangkaian detektor selubung yang telah dirancang memiliki lebar pulsa 12 ms dengan interval 1 detik dan bentuk sinyal ini tidak persis berbentuk pulsa.

3. Buzzer yang digunakan sebagai loud speaker mampu menghasilkan suara "ping" sekali setiap 1 detik. 


\section{DAFTAR RUJUKAN}

Sutoyo, Pranjoto, Gunadhi, dan Albert. (2014). Alat Uji Sinyal Ultrasonik dan Tegangan Baterai pada Underwater Locator Beacon. 13(1): 10-20.

Rustamaji, dan Elan Djaelani. (2015). Disain Band Pass Filter (BPF) Digital Dengan Metoda Window Untuk Memfilter Sinyal Pinger 37,5 kHz yang Dipancarkan Dari Beacon Black Box Locator. pp,29-31.

User's Manual. (2011). ELP-362D Underwater Locator Beacon. Teledyne Benthos, Inc. Dipetik pada 24 Juni 2015 dari http://teledynebenthos.com/_doc/main/ Brochures_Datasheets/elp362_001815_rev_L.pdf.

Robert F. Coughlin, dan Frederick F.Driscol. (1987). Operational Amplifiers and Integrated Circuits. New Delhi : PHI.

Bruce dan R. Brown. (2001). Handbook Of Operational Amplifier Applications. Texas Instruments. Dipetik pada 15 Juli 2015 dari www.ti.com/lit/an/sboa092a/sboa092a.pdf.

Donni. (2007). ELT Emergenncy Locator Transmitter. Dipetik pada 27 Juli 2015 dari http://www.odj.or.id/index2.php?option=com_content\&do_pdf. 